\title{
PARENTING STYLES AND THEIR IMPACTS ON CHILD PROBLEM BEHAVIORS
}

\author{
Agnes Maria Sumargi, Eli Prasetyo, Benedicta Winona Ardelia \\ Fakultas Psikologi, Universitas Katolik Widya Mandala Surabaya, \\ J1. Kalisari Selatan no. 1, Surabaya 60112 \\ agnesmariasumargi@yahoo.com
}

\begin{abstract}
Managing child problem behaviors as early as possible is crucial. Several studies have shown the impact of parenting on child problem behavior; however, the studies did not investigate the influence of paternal and maternal parenting on child behavior separately. This study aimed to test the effect of mothers' and fathers' authoritative and authoritarian parenting on child problem behavior. Furthermore, this study examined the influence of family adjustment on parenting styles. Participants were 105 pairs of parents (fathers and mothers). They completed a set of questionnaires assessing their parenting styles, child problem behavior, and family adjustment. Multiple regression analyses resulted in a significant effect of mothers' authoritative parenting on child emotional problems, as well as significant effects of fathers' authoritative and authoritarian parenting on child behavioral problems. Another key finding was that parental teamwork predicted the effectiveness of parenting.
\end{abstract}

Keywords: authoritative parenting; authoritarian parenting; family adjustment; problem behaviors; early childhood

\begin{abstract}
Abstrak
Perilaku bermasalah pada anak perlu ditangani sedini mungkin. Beberapa penelitian telah mengungkap dampak pengasuhan orangtua terhadap perilaku bermasalah anak namun umumnya tidak membedakan pengasuhan antara ayah dengan ibu. Penelitian ini secara khusus menguji pengaruh dari pengasuhan otoritatif dan otoriter ayah dan ibu terhadap perilaku bermasalah anak. Lebih jauh, penelitian ini juga mengungkap pengaruh dari faktor penyesuaian keluarga terhadap gaya pengasuhan yang dijalankan. Sebanyak 105 pasang orangtua (ayah dan ibu) terlibat dalam penelitian dengan mengisi kuesioner mengenai gaya pengasuhan, perilaku bermasalah anak, dan penyesuaian keluarga. Hasil analisis regresi ganda menunjukkan pengasuhan otoritatif ibu berpengaruh pada berkurangnya masalah emosi pada anak, sedangkan pengasuhan otoritatif ayah dan pengasuhan otoriter ibu berpengaruh signifikan pada masalah perilaku anak. Penelitian ini juga menemukan faktor kerja sama dalam mengasuh anak menentukan munculnya pengasuhan yang efektif atau tidak efektif dari orangtua.
\end{abstract}

Kata kunci: pengasuhan otoritatif; pengasuhan otoriter; penyesuaian keluarga; perilaku bermasalah; anak usia dini

\section{INTRODUCTION}

The first five years of a child's life are signified by dramatic changes in various aspects of development, such as physical, motoric, cognitive, and language development, as well as emotional and social development (Santrock, 2011a). During this time, parents have an important role in supporting child development, including teaching their child about social norms, good manners, and socially acceptable behaviors.
Parents also need to overcome their child's misbehaviors, such as fighting, breaking things, screaming, and shouting, as well as feeling shame and excessive fear (Williams et al., 2009). If problem behaviors are not managed earlier, it can develop into antisocial behaviors in late childhood, deviance or delinquency in adolescence (Murray \& Farrington, 2010), and even psychopathological problems, such as anxiety and behavior disorders, in adulthood (Reef, Diamantopoulou, van Meurs, 
Verhulst, \& van der Ende, 2011). Furthermore, research has shown that unmanaged child emotional and behavioral problems might affect academic performance at a later development (Bulotsky-Shearer \& Fantuzzo, 2011). In short, children with problem behaviors are subject to behavioral, social, and academic problems later in their life.

Problem behavior has two dimensions, namely the emotional and behavioral dimensions (Morawska, Sanders, Haslam, Filus, \& Fletcher, 2014) that are similar to internalizing and externalizing problems, respectively (Williams et al., 2009). Internalizing problems refer to neurotic behaviors, such as anxiety and fear, that indicate problems with self-esteem and social relationships (social withdrawal), while externalizing problems refer to disruptive or anti-social behaviors, such as shouting, fighting, and aggression, that indicate a desire to against others and violate rules or social norms (Morawska et al., 2014; Williams et al., 2009). The result of a parenting survey with parents of young children in different parts of Indonesia, such as Jakarta, Surabaya, Malang, Yogyakarta, and Bandung, showed that $4.81 \%$ of parents (9 out of 187 parents) indicated their child had a high level of emotional and behavioral problems (Sumargi, Sofronoff, \& Morawska, 2015). They reported a range of child problem behaviors including throwing tantrums when the child did not get what they wanted, refusing to follow parents' instructions to sleep, to put on their clothes, and to eat, whining, and fighting with their siblings or other children. Meanwhile, a study conducted among 1,779 young children in 79 kindergartens in Makassar (Ashary, Rahamma, \& Fatimah, 2015) showed that child behavioral problems that commonly occurred were aggression, including anger $(80.36 \%)$, and hitting and kicking others $(16.08 \%)$. Additionally, some children were reported to have emotional problems, such as anxiety manifested in the form of crying $(28.57 \%)$, not wanting to be left alone
(28.57\%), feeling restless $(12.50 \%)$, and difficulty eating $(8.93 \%)$. Some children also exhibited excessive fear of strangers $(36.30 \%)$ and fear of being in certain places or toward certain objects (47.62\%; Ashary, et al., 2015). The results are consistent with the findings of an exploratory qualitative study by Putri and Primana (2018) involving 9 preschool children aged 3-4 years in Jakarta. Aggression was the problem that predominantly occurred at school. This included hitting friends that were seen around $70 \%$ in the six occasions of observation. Further, young children in the study were often running around in class $(80 \%)$, shouting $(55 \%)$, and screaming $(20 \%)$.

Research has shown that family is the main predictor for problem behaviors in children and adolescence. A meta-analytic review by Pinquart (2017) involving 1,435 studies of parenting and child problem behaviors showed that punitive parenting practices, such as harsh discipline (physical and verbal punishment) and psychological control (induction of shame and guilt in children), were associated with child problem behaviors. Conversely, a warm relationship between parents and children has been shown to reduce child emotional and behavioral problems (Lansford, et al., 2014). According to Baumrind (2012), there are four parenting styles: authoritative, authoritarian, and permissive parenting. Authoritarian parents are lacking warmth and imposing strict limits, they can even punish and abuse their child (Santrock, 2011b). Baumrind (2012) states that authoritarian parenting is characterized by high demandingness and low responsiveness; in other words, parents excessively control their children. In contrast, authoritative parents are warm in their relations with their children and support their children's autonomy (Santrock, 2011b). Although parents set limitations to their child's behaviors, authoritative parents build good communication with their child. Authoritative parenting is characterized by high demandingness and high responsiveness 
(Baumrind, 2012). Meanwhile, the characteristics of permissive parenting is a lack of demands/rules and excessive responsiveness to their child (Baumrind, 2012). Permissive parents tend to spoil their child and give unlimited freedom with no demands (Santrock, 2011b). A study by Baumrind, Larzelere, and Owens (2010) showed that authoritarian parenting that was employed when children were at preschool negatively influenced children's development when they reached adolescence. Compared to those who were raised by authoritative and permissive parents, children who were raised by authoritarian parents had high levels of emotional and behavioral problems. Similar to the impact of authoritarian parenting, children whose parents were classified as permissive had higher levels of problem behaviors. In contrast, those who were raised by authoritative parents showed the lowest levels of emotional and behavioral problems. Akhter, Hanif, Tariq dan Atta (2011) reported the same results with school-aged children (8-12 years old). Positive correlations were found between authoritarian parenting and child problem behaviors, and between permissive parenting and child problem behavior, but a negative relationship was found between authoritative parenting and child problem behaviors.

Considering the impact of parenting styles on children's problem behaviors, it is important to examine the relationship between the two variables with children in early childhood. The earlier problem behaviors are detected, the faster they will be managed. In other words, parenting research involving children in early childhood indirectly contributes to the prevention and intervention of problem behaviors of young children to draw parents' attention to the issue. Up to now, parenting studies involving children in early childhood have been used as a basis for family intervention programs and policies (Katz, Coley, McDermott, McPherran, \& Yaya, 2010; Palm \& Cooke, 2018). The policies and early intervention programs are formed with the assumption that children are the most valuable asset of the nation, and therefore, their wellbeing requires a continuous monitoring (Katz, et al., 2010), and that children's relationship with their parents highly influences their wellbeing (Palm \& Cooke, 2018). Studies have shown that early implementation of family intervention or parenting programs has a positive impact on children's development as indicated by a decrease in the levels of children's problem behaviors (Piquero, et al., 2016).

It appears that studies of parenting and problem behaviors in early childhood, particularly in Indonesia, are still limited, and they did not consistently show significant results. In general, the existing research focuses only on a certain form of problem behaviors such as aggression (Hariyani, Marmawi, \& Sutarmanto, 2013; Rachmawati \& Hastuti, 2017) and temper tantrums (Watiningsih, Rismayanti, \& Sriastiyani, 2018; Zakiyah, 2017). For example, a study by Hariyani et al. (2013) involving 30 parents of children at a kindergarten in Pontianak revealed no significant relationships between parenting styles (rejection, overprotective, acceptance, and permissive parenting) and children's aggression (disturbing playmates, cursing, and bullying). On the contrary, a study by Rachmawati and Hastuti (2017) among 36 parents of young children in Ciasmara village, Bogor, showed that the significant predictors for children's aggressive behaviors (i.e., showing anger, using harsh words, and performing physical attacks) were negatively correlated with parenting practices characterized by strict discipline, anger, and inconsistent parenting. Another study by Zakiyah (2017) with 41 parents of children aged 1-3 years in Pelem, Bantul, indicated significant positive correlations between parenting styles and children's temper tantrums. The more often the parents employed positive parenting practices (showing affection and enforcing reasonable and consistent rules), the less often the child showed temper tantrums (whining, crying, 
and shouting). Watiningsih et al. (2018) reported similar findings in their study with 32 parents of young children (aged 1-3 years) in Kalibukbuk village, Bali. Democratic parenting was associated with lower occurrence of temper tantrums, while authoritarian or permissive parenting was associated with increased occurrence of temper tantrums. It is important to note that all the studies described above had used parenting measures made or modified by the researchers and the measures were given only to one parent. Although the aforementioned research showed significant relationships between parenting styles and children's aggression and temper tantrums, they only had a limited number of participants (ranging from 30 to 41 parents). This indicates the need to conduct a study on parenting and problem behaviors in early childhood using a more rigorous method to obtain more accurate results and a wider generality.

Similar to the study by Akhter et al. (2011), this current study involved both parents (fathers and mothers) and asked them to report their parenting styles and child behaviors. However, different from the study by Akhter et al. (2011), this current study focused on children at preschool age (1-5 years old). Thus, this study aimed to examine the effect of paternal and maternal parenting styles on young children's problem behaviors. Based on the previous findings, it was hypothesized that there would be significant effects of parenting styles (i.e., paternal and maternal parenting styles) on child problem behaviors.

This study also measured the impact of family adjustment on parenting styles. Family adjustment refers to a family's ability to respond to any changes and demands in the environment. Belsky (1984) stated that situations in the family, such as marital and family relations, affect the effectiveness of parenting. Sanders, Morawska, Haslam, Filus, and Fletcher (2014) added that family adjustment is an important factor that should be considered in a parenting study providing its impact on parenting and child behaviors. According to Sanders et al. (2014), family adjustment consists of three factors, including (1) parental emotional adjustment (parents' levels of stress, anxiety, and depression); (2) family relationships (the degree of social support and family conflicts); and (3) parental teamwork (the level of support received from the spouse when parenting their children). Several studies have shown significant, positive relationships of family adjustment factors with parenting, as well as with child behaviors (Guo, Morawska, \& Filus, 2017; Sanders et al., 2014: Sumargi, Filus, Morawska, \& Sofronoff, 2018). Low levels of emotional adjustment, family relationships, and parental teamwork were all associated with ineffective parenting and increased child problem behaviors. By examining the contribution of family adjustment to paternal and maternal parenting styles, the relationships between parenting styles and their predictors would be better understood. The second hypothesis in this study was that family adjustment factors would have significant effects on maternal and paternal parenting styles.

\section{METHOD}

\section{Participants}

Participants were 105 pairs of parents (fathers and mothers) residing in Surabaya and Sidoarjo who had a child aged 1 to 5 years. The demographic characteristics of fathers, mothers, and their children can be seen in Table 1.

The parents participated voluntarily in the study. They were recruited with help from schools (preschools/kindergartens/early childhood education centers) in Surabaya and Sidoarjo. Parents who agreed to participate completed informed consent. A series of questionnaires were distributed to the parents through the students at schools. As a token of appreciation, the researchers gave stationery 
or snacks to those who returned the questionnaire.

Table 1.

Participants' Demographic Characteristics

\begin{tabular}{|c|c|c|c|}
\hline Characteristics & Category & $n$ or Mean & $\%$ or $S D$ \\
\hline \multirow[t]{3}{*}{ Parent age } & Father & 37.08 & 6.55 \\
\hline & Mother & 34.97 & 6.25 \\
\hline & Child & 3.57 & 1.10 \\
\hline \multirow[t]{6}{*}{ Fathers' education level } & Primary school or lower & 2 & 1.90 \\
\hline & Junior high school & 3 & 2.86 \\
\hline & Senior high school & 41 & 39.05 \\
\hline & Diploma & 7 & 6.67 \\
\hline & Undergraduate & 49 & 46.67 \\
\hline & Postgraduate (master or doctorate) & 3 & 2.86 \\
\hline \multirow[t]{6}{*}{ Mothers' education level } & Primary school or lower & 2 & 1.90 \\
\hline & Junior high school & 4 & 3.81 \\
\hline & Senior high school & 47 & 44.76 \\
\hline & Diploma & 12 & 11.43 \\
\hline & Undergraduate & 39 & 37.14 \\
\hline & Postgraduate (master or doctorate) & 1 & 0.95 \\
\hline \multirow[t]{4}{*}{ Fathers' occupation } & Full time (> 35 hours/week) & 88 & 83.81 \\
\hline & Part-time & 7 & 6.67 \\
\hline & Casual or freelance & 7 & 6.67 \\
\hline & Unemployed & 3 & 2.86 \\
\hline \multirow[t]{4}{*}{ Mothers' occupation } & Full time (> 35 hours/week) & 8 & 7.62 \\
\hline & Part-time & 9 & 8.57 \\
\hline & Casual or freelance & 1 & 0.95 \\
\hline & Unemployed & 87 & 82.86 \\
\hline \multirow[t]{2}{*}{ Child gender } & Male & 54 & 51.43 \\
\hline & Female & 51 & 48.57 \\
\hline \multirow{3}{*}{ Child birth order } & First-born & 44 & 41.90 \\
\hline & Second-born & 39 & 37.14 \\
\hline & Third-born and beyond & 22 & 20.95 \\
\hline \multirow{5}{*}{$\begin{array}{l}\text { Child's current education } \\
\text { level }\end{array}$} & Not in school yet & 7 & 6.67 \\
\hline & $\begin{array}{l}\text { Early childhood education center } \\
\text { (PAUD) }\end{array}$ & 5 & 4.76 \\
\hline & Preschool & 12 & 11.43 \\
\hline & Kindergarten & 79 & 75.24 \\
\hline & Primary school (grade one) & 2 & 1.90 \\
\hline \multirow[t]{2}{*}{ Child care } & Taken care by parents & 96 & 91.43 \\
\hline & Taken care by grandparents & 9 & 8.57 \\
\hline \multirow[t]{4}{*}{ Time spent with fathers } & 1-5 hours/day & 47 & 44.76 \\
\hline & 6-10 hours/day & 45 & 42.86 \\
\hline & 11-15 hours/day & 10 & 9.52 \\
\hline & $>16$ hours/day & 3 & 2.86 \\
\hline \multirow[t]{4}{*}{ Time spent with mothers } & 1-5 hours/day & 3 & 2.88 \\
\hline & 6-10 hours/day & 11 & 10.58 \\
\hline & 11-15 hours/day & 14 & 13.46 \\
\hline & $>16$ hours/day & 76 & 73.08 \\
\hline
\end{tabular}




\section{Measures}

The Child Adjustment and Parent Efficacy Scale (CAPES; Morawska, et al., 2014), Intensity scale, was used to assess child emotional and behavioral problems. The number of items in the CAPES-Intensity is 27, consisted of two dimensions: Emotional problems (3 items; e.g., "My child worries") and Behavior problems (24 items; "My child loses their temper"). Each item is scored on a 4-point scale, ranging from 0 (Not at all) to 3 (Very much). The total score of behavior problems was calculated separately from the total score of emotional problems. The father's and mother's scores were averaged to obtain a child problem behavior score. The CAPES-Intensity had good construct validity and internal consistencies: .90 for the behavior problem scale and .74 for the emotional problem scale (Morawska, et al., 2014). In this current study, the internal consistencies for the behavioral problem scales rated by fathers and mothers were .88 and .84, respectively. The internal consistencies for the emotional problem scales rated by fathers and mothers were .73 and .75 , respectively.

$\begin{array}{llr}\text { The Parenting } & \text { Style } & \text { Dimension } \\ \text { Questionnaire-short } & \text { version } & \text { (PSDQ; }\end{array}$ Robinson, Mandleco, Olsen, \& Hart, 2001) was used to assess paternal and maternal parenting styles. The short version of PSDQ consists of 32 items with three main parts: 15 items of authoritative parenting which measure parental warmth, parental involvement, and parents' use of reasoning; 12 items of authoritarian parenting which measure parents' use of violence and punishment without using reasoning; and 5 items of permissive parenting which measure parents' spoiling behaviors. Example items were "I am responsive to my child's feelings and needs" and "I grab my child when being disobedient." Each item is scored on a 5-point scale, ranging from 1 (Never) to 5 (Always). The average scores were calculated separately for mothers' and fathers' parenting styles (authoritative, authoritarian, and permissive). The internal consistencies reported by Robinson et al. (2001) were .86 for the authoritative parenting scale, .82 for the authoritarian parenting scale, and .64 for the permissive parenting scale. In this current study, the internal consistencies of the authoritative and authoritarian parenting scales rated by fathers were .87 and .82 , respectively. The internal consistencies of the authoritative and authoritarian parenting scales rated by mothers were .80 and .83 , respectively. Notably, the internal consistencies of the permissive parenting scales rated by fathers and mothers were .46 and .54 , respectively. Given that the internal consistencies of the permissive parenting scale were poor, the scale was not included in the analyses. This study only used the authoritative and authoritarian parenting scales.

The Parenting and Family Adjustment Scale (PAFAS; Sanders et. al., 2014), Family adjustment subscale, was used to assess the adjustment ability of a family. The Indonesian version of the subscale consists of 8 items (Sumargi et al., 2018) divided into three factors: three items of parental adjustment, three items of family relationships, and two items of parental teamwork. Example items include "I feel stressed or worried" and "Our family members fight or argue." Each item is scored on a 4-point scale, ranging from 0 (Not at all) to 3 (Very much). The family adjustment scores for the three factors rated by mothers and fathers were calculated separately. Sumargi et al. (2018) reported the internal consistencies for the parental adjustment, family relationships, and parental teamwork subscales were $.67, .76$, and .76, respectively. In this current study, the internal consistencies of the family relationship subscales reported by fathers and mothers were .63 and .73 , respectively. The internal consistencies of the parental teamwork subscales reported by fathers and mothers were .76 and .73 , respectively. However, the internal consistencies of the parental adjustment subscales reported by fathers and mothers were poor; that was, .50 and .38, 
respectively. Thus, the parental adjustment subscale was not used in this study. Only the family relationships and parental teamwork subscales were used in the analyses.

Notably, all measures in this study had been translated into Indonesian by the first author and went through back translation and review processes conducted by judges who were competent in both English and Indonesian language. In other words, the translation was performed without changing the content and the number of items (following the permission obtained from the instrument developers). The three measures were included because previous studies in Indonesia had used the measures with fairly good internal consistencies (Sumargi et al., 2015; Sumargi et.al., 2018).

\section{Statistical Analyses}

Multiple regression analyses were performed to test the effect of paternal and maternal parenting styles on child problem behaviors (first hypothesis) and the effect of family adjustment factors on paternal and maternal parenting styles (second hypothesis).

For the first hypothesis testing, paternal authoritative and authoritarian parenting, as well as maternal authoritative and authoritarian parenting were classified as the independent variables, whilst child problem behavior was classified as the dependent variable. For the second hypothesis testing, family relationships and parental teamwork were classified as the independent variables, and paternal and/or maternal parenting styles that were found to have significant impacts on child problem behaviors (first hypothesis testing) were classified as the dependent variables. Data analyses were performed using the SPSS for Windows software (version 25).

\section{RESULTS AND DISCUSSION}

In this study, missing values were less than $5 \%$ on both paternal $(.03 \%)$ and maternal data $(.13 \%)$. The Little's MCAR test showed that data were missing completely at random (MCAR) and had no relationship with the study variables, $\chi^{2}(134, n=105)=147.77, p$ $=.196$ for fathers' data and $\chi^{2}(330, n=105)$ $=302.62, p=.858$ for mothers' data. Therefore, missing data could be ignored or replaced with any method (Graham, 2009). This study used the ExpectationMaximization (EM) method to replace the missing values.

Meanwhile, any extreme scores (outliers) in fathers' and mothers' data were changed into the closest value that was below or above the scores using the winsorizing method (Field, 2013) before it was further analyzed. The Mahalanobis Distances indicated no multivariate outliers in the data for the first hypothesis testing, but there were multivariate outliers in the data for the second hypothesis testing. Given that Cook's Distances for the outliers were relatively small, they did not significantly affect the results of the study, and therefore, the outliers were not removed.

As seen in Table 2, the multicollinearity assumptions in the first and second hypothesis testing were met based on Tolerance and VIF values. The linearity and homoscedasticity assumptions were also met based on the results of the scatter plot of the standardized residuals versus standardized predicted values, and the Glejser test for homoscedasticity. Meanwhile, the assumption testing for normality using the Kolmogorov Smirnov test showed that data were normally distributed, except for the following variables: emotional problems (the CAPES-Emotional problems), family relationships (the PAFAS-Family relationships), and parental teamwork (the PAFAS-Parental teamwork). Although the transformation of data had been applied, data were still not normally distributed. Therefore, it was decided to use the original data in the analyses. 
Table 2.

Results of Assumption Testing for Multicollinearity

Variables

Tolerance VIF

First hypothesis:

The effect of parenting styles on child emotional and behavioral problems

Paternal authoritative parenting .76

Paternal authoritarian parenting

$.52 \quad 1.91$

Maternal authoritative parenting

$.76 \quad 1.32$

Maternal authoritarian parenting

$.53 \quad 1.91$

Second hypothesis:

The effect of family adjustment on paternal authoritative parenting

Family relationships reported by fathers

$.69 \quad 1.45$

Parental teamwork reported by fathers

$.69 \quad 1.45$

The effect of family adjustment on maternal authoritative and authoritarian parenting

Family relationships reported by mothers .70

Parental teamwork reported by mothers

$.70 \quad 1.43$

Note. Multicollinearity occurs if the tolerance value is less than .10 and the VIF (Variance Inflation Factor) value is more than 10 (Pallant, 2010).

The effect of parenting styles on child problem behaviors

Table 3 shows the results of product-moment correlations of paternal and maternal parenting styles with child emotional and behavioral problems (child problem behaviors). Paternal and maternal authoritative parenting had significant negative relationships with child emotional and behavioral problems. The more often the fathers and mothers used authoritative parenting, the less emotional and behavioral problems the children had. Notably, paternal authoritarian parenting was not significantly associated with child emotional and relationship between maternal authoritarian parenting and child emotional problems was not significant either. However, maternal authoritarian parenting had a significant positive relationship with child behavioral problems. The more often the mothers used authoritarian parenting, the more often the child showed behavioral problems. Inspecting the mean and standard deviation of maternal authoritarian parenting, the mean appeared higher than that of paternal authoritarian parenting. An independent t-test revealed that mothers used authoritarian parenting more often than fathers, $t(208)=$ behavioral problems. The $-2.08, p=.039$. 
Table 3.

Product-Moment Correlations between Paternal and Maternal Parenting Styles and Child Problem Behaviors

\begin{tabular}{|c|c|c|c|c|c|c|}
\hline Variables & 1 & 2 & 3 & 4 & 5 & 6 \\
\hline 1. Child emotional problems ${ }^{\mathrm{a}}$ & - & & & & & \\
\hline 2. Child behavioral problems ${ }^{a}$ & $.47^{* * *}$ & - & & & & \\
\hline 3. Paternal authoritative parenting ${ }^{\mathrm{b}}$ & $-.24^{*}$ & $-.38^{* * *}$ & - & & & \\
\hline 4. Paternal authoritarian parenting & -.03 & .14 & .10 & - & & \\
\hline 5. Maternal authoritative parenting & $-.30^{* *}$ & $-.25^{*}$ & $.47^{* * *}$ & .15 & - & \\
\hline 6. Maternal authoritarian parenting & .05 & $.30^{* *}$ & -.00 & $.68^{* * *}$ & .13 & - \\
\hline$M e a n^{\mathrm{c}}$ & 1.25 & 20.35 & 3.77 & 1.97 & 3.91 & 2.14 \\
\hline Standard Deviation $^{\mathrm{c}}$ & 1.36 & 7.96 & 0.59 & 0.57 & 0.51 & 0.62 \\
\hline
\end{tabular}

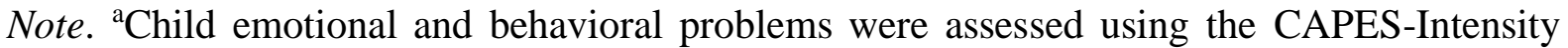
and the scores were based on fathers' and mothers' ratings. 'Paternal and maternal authoritative and authoritarian parenting styles were assessed using the PSDQ. ${ }^{c} n$ fathers $=$ 105 and $n$ mothers $=105 .{ }_{p}^{*}<.05 .{ }^{* *} p<.01 .{ }^{* * *} p<.001$.

Multiple regression analysis with paternal and maternal parenting as the predictors and child emotional problem as the dependent variable revealed that the model was significant, $F(4,100)=3.20, p=.016$. The contribution of the four parenting styles to child emotional problems was $11 \%$. As seen in Table 4, only maternal authoritative parenting made a unique and significant contribution to child emotional problems.

Table 4.

Multiple Regression Analysis with Maternal and Paternal Parenting Styles as Predictors and Child Problem Behaviors as Dependent Variables

\begin{tabular}{lcccccc}
\hline & \multicolumn{3}{c}{ Emotional problems } & \multicolumn{3}{c}{ Behavioral problems } \\
\cline { 2 - 7 } Variables & $b$ & $S E b$ & $b^{*}$ & $b$ & $S E b$ & $b^{*}$ \\
\hline Constant & 4.57 & 1.12 & & 35.96 & 6.06 & \\
Paternal authoritative parenting & -0.25 & 0.25 & -0.11 & -4.05 & 1.34 & $-0.30^{* * *}$ \\
Paternal authoritarian parenting & -0.16 & 0.31 & -0.07 & -0.69 & 1.68 & -0.05 \\
Maternal authoritative parenting & -0.68 & 0.29 & $-0.26^{*}$ & -2.23 & 1.55 & -0.14 \\
Maternal authoritarian parenting & 0.29 & 0.29 & 0.13 & 4.55 & 1.55 & $0.35^{* *}$ \\
& & & & & & \\
$R^{2}$ & & 0.11 & & & 0.25 & \\
$F$ & & $3.20^{*}$ & & & & \\
\end{tabular}

Note. $b=$ unstandardized coefficients, $b^{*}=$ standardized coefficients (beta).

${ }^{*} p<.05,{ }^{* *} p<.01,{ }^{* * *} p<.001$.

Multiple regression analysis with paternal and maternal parenting styles as the predictors and child behavioral problems as the dependent variable revealed that the model was significant, $F(4,100)=8.22, p<$ .001 . The contribution of the four parenting styles to child behavioral problems was $25 \%$. As seen in Table 4, paternal authoritative and maternal authoritarian parenting made unique and significant contributions to the child behavioral problems.

\section{The effect of family adjustment on paternal and maternal parenting styles}

Based on the previous analyses that maternal authoritative parenting made a significant contribution to child emotional problems and 
that paternal authoritative and maternal authoritarian parenting made significant contributions to child behavioral problems, the next analysis were conducted to test the effect of family adjustment factors on maternal authoritative parenting, paternal authoritative parenting, and maternal authoritarian parenting.

The correlational analyses between family adjustment factors (family relationships and parental teamwork), maternal and paternal authoritative parenting, and maternal authoritarian parenting can be seen in Table 5. The table shows that only parental teamwork reported by fathers had a significant negative correlation with paternal authoritative parenting. The more often the fathers experienced parental teamwork problems (based on fathers' reports), the less often the fathers used authoritative parenting. Meanwhile, for mothers, family relationships and parental teamwork did not have significant relationships with maternal authoritative parenting, but had significant positive correlations with maternal authoritarian parenting. Thus, the more often the mothers experienced family relationship problems and parental teamwork problems (based on mothers' reports), the more often the mothers used authoritarian parenting.

Table 5.

Product-Moment Correlations between Family Adjustment Factors, and Paternal and Maternal Parenting Styles

\begin{tabular}{|c|c|c|c|c|c|c|c|}
\hline Variables & 1 & 2 & 3 & 4 & 5 & 6 & 7 \\
\hline 1. Paternal authoritative parenting ${ }^{\mathrm{a}}$ & - & & & & & & \\
\hline 2. Maternal authoritative parenting ${ }^{\mathrm{a}}$ & $.47^{* * * *}$ & - & & & & & \\
\hline 3. Maternal authoritarian parenting & -.00 & .13 & - & & & & \\
\hline $\begin{array}{l}\text { 4. Family relationships reported by } \\
\text { fathers }^{\mathrm{b}}\end{array}$ & -.17 & .02 & $.33^{* *}$ & - & & & \\
\hline $\begin{array}{l}\text { 5. Parental teamwork reported by } \\
\text { fathers }{ }^{\mathrm{b}}\end{array}$ & $-.34^{* * *}$ & -.12 & $.40^{* * *}$ & $.56^{* * *}$ & - & & \\
\hline $\begin{array}{l}\text { 6. Family relationships reported by } \\
\text { mothers }{ }^{b}\end{array}$ & $-.24^{*}$ & -.09 & $.33^{* * *}$ & $.51^{* * *}$ & $.54^{* * *}$ & - & \\
\hline $\begin{array}{l}\text { 7. Parental teamwork reported by } \\
\text { mothers }^{\mathrm{b}}\end{array}$ & $-.24^{*}$ & -.13 & $.54^{* * *}$ & $.34^{* * *}$ & $.57^{* * *}$ & $.55^{* * *}$ & - \\
\hline $\operatorname{Mean}^{c}$ & 3.77 & 3.91 & 2.14 & 1.32 & 0.48 & 1.17 & 0.47 \\
\hline Standard Deviation $^{c}$ & 0.59 & 0.51 & 0.62 & 1.36 & 0.88 & 1.40 & 0.87 \\
\hline
\end{tabular}

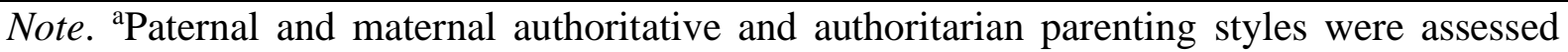
using the PSDQ. ${ }^{b}$ Family relationships and parental teamwork reported by fathers and mothers were assessed using the PAFAS-Family Adjustment ${ }^{\mathrm{c}} n$ fathers $=105$ and $n$ mothers $=105 .{ }^{*} p<.05 .{ }^{* *} p<.01 .{ }^{* * *} p<.001$.

A series of multiple regression analyses were conducted for paternal authoritative parenting and maternal authoritative and authoritarian parenting. With paternal authoritative parenting as the dependent variable, and family relationships and parental teamwork reported by fathers as the predictors, the regression model was significant, $F(2,102)=6.69, p=.002$. The contribution of the two family adjustment factors to paternal authoritative parenting was $12 \%$. As seen in Table 4 , only parental teamwork made a unique and significant contribution to paternal authoritative parenting. 
Table 6.

Multiple Regression Analysis with Family Adjustment Factors as Predictors and Paternal and Maternal Parenting Styles as Dependent Variables

Paternal authoritative Maternal authoritarian

\begin{tabular}{|c|c|c|c|c|c|c|}
\hline \multirow[b]{2}{*}{ Variables } & \multicolumn{3}{|c|}{ parenting } & \multicolumn{3}{|c|}{ parenting } \\
\hline & $b$ & $S E b$ & $b^{*}$ & $b$ & $S E b$ & $b^{*}$ \\
\hline Constant & 3.87 & .08 & & 1.95 & .07 & \\
\hline Family relationships reported by fathers & .01 & .05 & .03 & & & \\
\hline Parental teamwork reported by fathers & -.24 & .08 & $-.36^{* *}$ & & & \\
\hline Family relationships reported by mothers & & & & .02 & .04 & .05 \\
\hline Parental teamwork reported by mothers & & & & .36 & .07 & $.51^{* * * *}$ \\
\hline$R^{2}$ & .12 & & & .29 & & \\
\hline$F$ & $6.69^{* *}$ & & & 20.61 & & \\
\hline
\end{tabular}

Note. $b=$ unstandardized coefficients, $b^{*}=$ standardized coefficients (beta). ${ }^{* *} p<.01 .{ }^{* * *} p<$ .001 .

Multiple regression analysis with family relationships and parental teamwork reported by mothers as the predictors revealed that the model for maternal authoritative parenting was not significant, $F(2,102)=.92, p=.404$. This is consistent with the correlational analyses indicating that the associations between family relationships reported by mothers and maternal authoritative parenting and between parental teamwork reported by mothers and maternal authoritative parenting (Table 3) were not significant.

Meanwhile, multiple regression analysis with family relationships and parental teamwork reported by mothers as the predictors and maternal authoritarian parenting as the dependent variable revealed that the model was significant, $F(2,102)=20.61, p<.001$. The contribution of the two-family adjustment factors to maternal authoritarian parenting was $29 \%$. As seen in Table 6, only parental teamwork made a unique and significant contribution to maternal authoritarian parenting.

Based on the results above, there were significant effects of paternal and maternal parenting styles on child problem behaviors. In particular, child emotional problems were significantly influenced by maternal authoritative parenting, and child behavioral problems were significantly influenced by paternal authoritative parenting and maternal authoritarian parenting. The more often the mothers used authoritative parenting, the less emotional problems the children had. Also, the more often the fathers used authoritative parenting and the less often the mother used authoritarian parenting, the less behavioral problems the children had.

The overall results in this study are consistent with the previous findings that showed the positive relationship between authoritative parenting and problem behaviors among preschool children (Cheah, Leung, Tahseen, \& Schultz, 2009). Authoritative parents encourage children to be more mature, developing their social and emotional competence (Baumrind, 2012). In contrast, authoritarian parents lack warmth, have strict limitations, and use punishment to control children's behaviors. This practice can be detrimental to children's development. Parents' high demands and the use of physical and verbal punishment can trigger problem behaviors in children (Chan, 2010; Murray \& Farrington, 2010; King, Vidourek, \& Merianos, 2016).

This study confirms and extends the previous findings because this study involves both parents (fathers and mothers) as participants. 
It was found that mothers used authoritarian parenting more frequently than fathers and authoritarian parenting was associated with behavioral problems in children. In contrast, paternal authoritative parenting had a positive impact on child behavior. This study found child behavioral problems decreased when mothers used authoritarian parenting less frequently and when fathers used authoritative parenting more frequently. For child emotional problems, maternal authoritative parenting seemed to play an important role because its use might reduce child emotional problems. Thus, paternal and maternal parenting styles had different contributions to child problem behaviors.

The results concerning the impact of paternal and maternal parenting styles on child problem behaviors differ slightly from the findings of Akhter et al. (2011) with primary school students in Pakistan. In this current study, maternal authoritarian parenting was not the only significant predictor for child behavioral problems. Paternal authoritarian parenting also predicted child behavioral problems. The differences in the results may be due to differences in the characteristics of participants. This study involved parents of young children $(M=3.57$ years old; $S D=$ 1.10), while the study by Akhter et al. (2011) involved parents of school-aged children. School-aged children have more advanced cognitive development than children in early childhood; thus, they are expected to have a better understanding of rules and social norms (Santrock, 2011b). Furthermore, school-aged children have to do more academic works at school than children in early childhood. Fathers might play an important role in introducing and teaching social norms to school-aged children as these children are more independent and have better communication skills than young children. Meanwhile, for children in early childhood, mothers play an important role because young children still need a great deal of physical care and guidance. Demographic data support this argument: the majority of the participating mothers $(82.86 \%)$ were housewives, and the majority of participating fathers $(83.81 \%)$ worked full time, and therefore, they had less time to be with their children. As children spent more time with their mothers, maternal parenting seemed to have more influence than paternal parenting over child behaviors. Mothers were more often than fathers to deal with a range of child behaviors, including child problem behaviors. This can be seen from the higher authoritative and authoritarian parenting scores of mothers compared to those of fathers (see Table 1). Furthermore, maternal authoritarian parenting, and not paternal authoritarian parenting, was found to have a significant impact on child behavioral problems.

Although paternal parenting was less influential than maternal parenting over child behaviors, paternal authoritative parenting was found to contribute to reduced problem behaviors in young children. Based on the dimensions of authoritative parenting (Robinson, et al, 2001), what children need from their fathers is warmth and support (for example, communication, understanding, and comfort), an explanation of the rules (for example, an explanation of the feelings and consequences caused by child behaviors), and opportunities to be independent or express their opinions.

Paternal authoritative parenting could prevent and overcome child problem behaviors, such as temper tantrums, fights, whining, resistance, and other disruptive behaviors. This is consistent with the previous finding showing that authoritative parenting used by both parents or at least by one parent could reduce child problem behaviors (Linares, Torre, Carpio, Cerezo, \& Casanova, 2014). This study also found that there were significant effects of family adjustment factors on paternal authoritative parenting and maternal authoritarian parenting. The family adjustment factor that significantly predicted parenting styles was parental teamwork. Thus, if fathers perceived that they could work together with mothers 
when parenting their child (they did not have parental teamwork problems), then fathers were more likely to use authoritative parenting. Meanwhile, if mothers perceived that they had poor parental teamwork with fathers (e.g., not receiving much help from fathers), then mothers were more likely to use authoritarian parenting. It should be noted, however, this study did not find any significant effect of family adjustment factors on maternal authoritative parenting.

In general, the contribution of family adjustment factors to parenting is in line with the theoretical model proposed by Belsky (1984). Belsky (1984) indicates that marital relationship, family relationships, and social support influence parenting that subsequently influence child development. The results of this study confirm the findings in the previous studies that showed significant relationships between parenting effectiveness and family adjustment factors such as family relationships and parental teamwork (Guo et al., 2017; Sanders et al., 2014; Sumargi et al., 2018). Furthermore, this study extends the previous findings by revealing the main predictor for paternal authoritative parenting and maternal authoritarian parenting, which was parental teamwork. Parental teamwork was found to reduce the use of maternal authoritarian parenting and increase the use of paternal authoritative parenting. This is supported by the fact that almost all participants in this study $(91.35 \%)$ did their parenting without help from other child caregivers, such as grandparents and housemaids. Thus, the effectiveness of fathers' and mothers' parenting depends on the quality of teamwork between fathers and mothers in parenting their children.

Notably, the absence of the effect of family adjustment factors on maternal authoritative parenting which determined child emotional problems indicates that other factors may significantly influence maternal authoritative parenting. One possibility is maternal psychological well-being. Cheah et al. (2009) found significant associations of psychological well-being and stress with authoritative parenting among mothers of preschool children. In low-stress conditions, mothers with high levels of psychological well-being used authoritative parenting more often. This current study has not yet considered parenting stress and maternal psychological well-being as the study variables. Further research could explore the effect of these variables on maternal authoritative parenting.

\section{CONCLUSION}

The results confirm the first hypothesis, indicating that there were significant effects of paternal and maternal parenting styles on child problem behaviors. The significant predictor of child emotional problems was maternal authoritative parenting and the significant predictors of child behavioral problems were paternal authoritative parenting and maternal authoritarian parenting. Further, the second hypothesis is also confirmed, showing that there were significant effects of family adjustment factors on paternal and maternal parenting styles. The family adjustment factor that made a significant contribution to paternal authoritative parenting was parental teamwork. Parental teamwork was also a significant predictor for maternal authoritarian parenting. However, there was no significant effect of family adjustment factors on maternal authoritative parenting. This study has limitations, including not being able to reveal the contribution of permissive parenting to child problem behaviors and to investigate the role of parental adjustment in parenting due to the poor internal consistencies of the PSDQPermissive and the PAFAS-Parental adjustment. Future research could use other 
measures that are more reliable in assessing the variables, such as the DASS-21 (Depression Anxiety Stress Scale-21) to examine parental stress as research showed that its internal consistency was excellent among Indonesian parents $(\alpha=0.95$; Krisnana, Sulistyarini, Rachmawati, Arief, \& Kurnia, 2019). For the PSDQ, Riany, Cuskelly, and Meredith (2018) revealed that permissive parenting was not a parenting style for Indonesian parents. Instead, parenting with reasoning might replace permissive parenting style (Riany et al., 2018). Future research should also involve a larger number of participating parents to enable the use of more advanced statistical analyses such as Structural Equation Modelling (SEM). Despite its limitations, this study extends the results of previous studies by revealing the crucial role of parental teamwork in paternal and maternal parenting styles. This study shows that paternal and maternal authoritative parenting styles have positive impacts on child behaviors, whereas maternal authoritarian parenting has the potential to increase child problem behaviors.

\section{REFERENCES}

Akhter, N., Hanif, R., Tariq, N., \& Atta, M. (2011). Parenting style as predictors of externalizing and internalizing behavior problems among children. Pakistan Journal of Psychological Research, 26(1), 23-41.

Ashary, Y., Rahamma, T., \& Fatimah, J. M. (2015). Pengendalian perilaku emosional anak TK melalui komunikasi antara guru dengan orang tua di kecamatan Biringkanaya kota Makassar. Kareba: Jurnal Ilmu Komunikasi, 4(4), 415-434.

Baumrind, D. (2012). Differentiating between confrontive and coercive kinds of parental power-assertive disciplinary practices. Human Development, 55(2), 35-51. doi: 10.1159/000337962
Baumrind, D., Larzelere, R. E., \& Owens, E. B. (2010). Effects of preschool parents' power assertive patterns and practices on adolescent development. Parenting: Science and Practice, 10(3), 157-201. doi: 10.1080/15295190903290790

Belsky, J. (1984). Determinants of parenting: A process model. Child Development, 55(1), 83-96. doi: 10.1111/j.14678624.1984.tb00275.x

Bulotsky-Shearer, R. J., \& Fantuzzo, J. W. (2011). Preschool behavior problems in classroom learning situations and literacy outcomes in kindergarten and first grade. Early Childhood Research Quarterly, 26(1), 61-73. doi:10.1016/j.ecresq.2010.04.004

Chan, S. M. (2010). Aggressive behaviour in early elementary school children: Relations to authoritarian parenting, children's negative emotionality and coping strategies. Early Child Development and Care, 180(9), 12531269. doi: 10.1080/03004430902981447

Cheah, C.S. L., Leung, C.Y.Y., Tahseen, M., \& Schultz, D. (2009). Authoritative parenting among immigrant Chinese mothers of pre-schoolers. Journal of Family Psychology, 23, 311-320. doi:10.1037/a0015076

Field, A. (2013). Discovering statistics using IBM SPSS statistics (4 ${ }^{\text {th }}$ edition). Los Angeles: Sage.

Graham, J. W. (2009). Missing data analysis: Making it work in the real world. Annual Review of Psychology, 60(1), 549-576. doi:

10.1146/annurev.psych.58.110405.0855 30

Guo, M., Morawska, A., \& Filus, A. (2017). Validation of the Parenting and Family Adjustment Scales to measure parenting skills and family adjustment in Chinese parents. Measurement and Evaluation in Counseling and Development, 50(3), 
139-154.

doi:10.1177/0748175615625754

Hariyani, I, Marmawi, R., \& Sutarmanto (2013). Hubungan pola asuh orangtua dengan perilaku agresivitas anak TK Kemala Bhayangkari 13. Jurnal Pendidikan dan Pembelajaran, 2(4), 1-8.

Katz, I., Coley, R. L., McDermott, S., McPherran, C., \& Yaya, I. (2010). A policy framework for parenting: Final report. Sydney: Social Policy Research Centre, University of New South Wales. Diambil dari https://www.arts.unsw.edu.au/sites/defau lt/files/documents/A_Policy_Framework _for_Parenting_Final_Report.pdf

King, K.A., Vidourek, R.A., \& Merianos, A.L. (2016). Authoritarian parenting and youth depression: Results from a national study. Journal of Prevention and Intervention in the Community, 44(2), 130-139. doi: $10.1080 / 10852352.2016 .1132870$

Krisnana, I., Sulistyarini, H., Rachmawati, P. D., Arief, Y. S., \& Kurnia, I. D. (2019). Reducing acute stress disorders in mothers of leukemic children by means of the Family Centered Empowerment module (FACE). Central European Journal of Nursing and Midwifery, 10(2), 1035-1040. doi: 10.15452/CEJNM.2019.10.0011

Lansford, J. E., Sharma, C., Malone, P. S., Woodlief, D., Dodge, K. A., Oburu, P., ... \& Giunta, L. D. (2014). Corporal punishment, maternal warmth, and child adjustment: A longitudinal study in eight countries. Journal of Clinical Child \& Adolescent Psychology, 43(4), 670-685. doi: 10.1080/15374416.2014.893518

Linares, M.C.G., Torre, M.J., Carpio, M.V., Cerezo, M.T., \& Casanova, P.F. (2014). Consistency/inconsistency in paternal and maternal parenting styles and daily stress in adolescence. Revista de
Psicodidáctica, 19(2), 307-325. doi: 10.1387/RevPsicodidact.7219

Morawska, A., Sanders, M. R., Haslam, D., Filus, A. \& Fletcher, R. (2014). Child Adjustment and Parent Efficacy Scale: Development and initial validation of a parent report measure. Australian Psychologist, 49(4), 241-252. doi: 10.1111/ap. 12057

Murray, J., \& Farrington, D. P. (2010). Risk factors for conduct disorder and delinquency: key findings from longitudinal studies. The Canadian Journal of Psychiatry, 55(10), 633-642. doi: 10.1177/070674371005501003

Pallant, J. (2010). SPSS survival manual: A step by step guide to data analysis using SPSS. Berkshire, England: Open University Press.

Palm, G., \& Cooke, B. (2018). Parent education and family life education: A critical link in early childhood education policy. National Council on Family Relations: Policy Brief, 3(2), 1-6. Diambil dari https://www.ncfr.org/sites/default/files/2 018-

07/Policy\%20Brief\%20July\%202018.pd $\mathrm{f}$

Pinquart, M. (2017). Associations of parenting dimensions and styles with externalizing problems of children and adolescents: An updated meta-analysis. Developmental Psychology, 53(5), 873932. doi: 10.1037/dev0000295

Piquero, A. R., Jennings, W. G., Diamond, B., Farrington, D. P., Tremblay, R. E., Welsh, B. C., \& Gonzalez, J. M. R. (2016). A meta-analysis update on the effects of early family/parent training programs on antisocial behavior and delinquency. Journal of Experimental Criminology, 12(2), 229-248. doi: 10.1007/s11292-016-9256-0

Putri, C. I. H., \& Primana, L. (2018). Gambaran perilaku disregulasi emosi 
anak prasekolah usia 3-4 tahun. Jurnal Ilmiah Psikologi Terapan, 6(1), 102110. doi: 10.22219/jipt.v6i1.5113

Rachmawati \& Hastuti (2017). Parental selfefficacy dan praktik pengasuhan menentukan perilaku agresif anak usia prasekolah. Jurnal Ilmu Keluarga \& Konsumen, 10, 227-237. doi: 10.24156/jikk.2017.10.3.227

Reef, J., Diamantopoulou, S., van Meurs, I., Verhulst, F. C., \& van der Ende, J. (2011). Developmental trajectories of child to adolescent externalizing behavior and adult DSM-IV disorder: Results of a 24-year longitudinal study. Social Psychiatry and Psychiatric Epidemiology, 46(12), 1233-1241. doi: 10.1007/s00127-010-0297-9

Riany, Y. E., Cuskelly, M., \& Meredith, P. (2018). Psychometric properties of parenting measures in Indonesia. Makara Human Behavior Studies in Asia, 22(2), 75-90. doi: 10.7454/hubs.asia.1160118

Robinson, C.C., Mandleco, B., Olsen, S.F., \& Hart, C.H. (2001). The Parenting Styles and Dimensions Questionnaire (PSDQ). In B. F. Perlmutter, J. Touliatos, \& G. W. Holden (Eds.), Handbook of family measurement techniques: Vol. 3. Instruments \& index (pp. 319 - 321). Thousand Oaks: Sage.

Sanders, M., Morawska, A., Haslam, D., Filus, A., \& Fletcher, R. (2014). Parenting and Family Adjustment Scale (PAFAS): Validation of a brief parentreport measure for use in assessment of parenting skills and family relationships. Child Psychiatry and Human Development, 45(3), 255-272. doi: $10.1007 / \mathrm{s} 10578-013-0397-3$

Santrock, J. W. (2011a). Child development (13 ${ }^{\text {th }}$ edition). New York: McGraw-Hill.
Santrock, J. W. (2011b). Life span development $\left(13^{\text {th }}\right.$ edition). New York: McGraw-Hill.

Sumargi, A., Filus, A., Morawska, A., \& Sofronoff, K. (2018). The Parenting and Family Adjustment Scales (PAFAS): An Indonesian validation study. Journal of Child and Family Studies, 27(3), 756770. doi: 10.1007/s10826-017-0926-y

Sumargi, A., Sofronoff, K., \& Morawska, A. (2015). Understanding parenting practices and parents' views of parenting programs: A survey among Indonesian parents residing in Indonesia and Australia. Journal of Child and Family Studies, 24(1), 141-160. doi: 10.1007/s10826-013-9821-3.

Watiningsih, A. P., Rismayanti, I. D. A., \& Sriastiyani, N. N. (2018). Hubungan pola asuh orangtua terhadap perilaku temper tantrum pada anak usia toddler di desa Kalibukbuk [The relationship between parenting style and temper tantrums at toddler age children in the Kalibukbuk Village]. Jurnal Kesehatan Midwinerslion, 3(2), 175-180.

Williams, L. R., Degnan, K. A., Perez-Edgar, K. E., Henderson, H. A., Rubin, K. H., Pine, D. S., ... \& Fox, N. A. (2009). Impact of behavioral inhibition and parenting style on internalizing and externalizing problems from early childhood through adolescence. Journal of Abnormal Child Psychology, 37(8), 1063-1075. doi:10.1007/s10802-0099331-3.

Zakiyah, N. (2017). Hubungan pola asuh orangtua dengan kejadian temper tantrum pada usia toddler di Dukuh Pelem Kelurahan Baturetno Banguntapan Bantul. Interest, Jurnal Terpadu Ilmu Kesehatan, 6(1), 62-71. 